THE ARCTIC LYMANTRIID LARVA FROM MT. WASHINGTON, N. H. (DASYCHIRA ROSSII CURT.?)

\author{
BY HARRISON G. DYAR, NEW YORK, N. Y.
}

About twenty years ago, Mr. Grote recorded (Psyche, I, I3I) the capture on Mt. Washington, above timber line, of an Arctic form of Lymantriidae which he referred to as a variety of Laria rossii Curtis. Last summer a number of larvae occurred to me on Vaccinium and Betula near the summit which I believe to be the larvae of this species. Others were found by Mrs. A. T. Slosson and, near the top of Mt. Adams, by Master Richard Seager. The larvae do not agree with Dr. Packard's description of Laria rossii (Amer. Nat. xi, 52) taken by the Polaris expedition in northern Greenland, but neither did his moths quite correspond, and he may have had before him examples of Dasychira groenlandica in which the hind wings are colored as he describes. The original locality for rossii in Boothia is much nearer to our own region than is northern Greenland, and true rossii has been recorded from Labrador by Christoph and Möschler; hence it seems probable that the Mt. Washington race should prove more like these. The moths are actually so, showing the yellowish color on the hind wings.

There seems little doubt but that these Arctic forms are branches of a race represented in Europe by Dasychira selenitica. If we remove from the larva of selenitica the slender hair pencils which arise from joints 2 and I2, we should have a very close approximation to the larva described by Dr. Packard; and if we further modify the same larva by adding tufts on joints Io and I I, like those already present on joints 5 to 9 and $\mathrm{I} 2$, we should have practically the Mt. Washington larva.

Curtis describes the larva of $D$. rossi as follows: "Large and hairy, of a beautiful shining velvety black, the hairs being somewhat ocherous; there are two tufts of black on the back, followed by two of orange." Unfortunately this meagre statement leaves the question open as to whether $D$. rossii is like Dr. Packard's larva or mine. Perhaps the " two black and two orange tufts" refers to the younger stages; it cannot refer to either Dr. Packard's mature larva or to mine. In the rest. of the description there is no mention of the absence of tufts from joints ro and II, and the presumption would be that the larvae were uniformly tufted like my Mt. Washington ones. However, I recognize that too much weight should not be given to omissions in such imperfect descriptions.

The following is a description of the $\mathrm{Mt}$. Washington larvae: Head rounded, velvety brown-black, densely hairy; clypeus black, smooth; a reddish shade on the posterior side of head; width $3.2 \mathrm{~mm}$. Warts normal 
for the Lymantriidae; three above the stigmatal wart on joints 3 and 4 ; wart $i$ moderately large on abdomen; wart iv very small, behind the spiracle; leg plates distinct. Dorsal eversible areas on joints ro and I normal, whitish, more or less concealed by the hair, often completely so. Body black with a frosty gray shade; hair thick, all barbuled, some heavily feathered but none plumed. Tufts from warts $i$ on joints 5 to 9 and i2 a little more closely bunched, but no true tufts and no pencils. Hair gray, mixed with black, with bright yellow hairs on the lower side of wart ii on joints 5 to 13 and at the bases of all the hair bunches on the thorax. Subventral hair bunches small. The gray hairs are densely feathery on warts $i$ to $v$, the black and yellow ones only spinulose. Hair not very long, quite even but not regularly so.

\section{NOTES ON THE SPECIES OF EXORISTA OF TEMPERATE NORTH AMERICA.}

BY C. H. TYLER TOWNSEND, LAS CRUCES, N. MEX.

The following twelve species of Exorista all belong to the middle and eastern United States with one exception, E. lagoae being from Guanajuato on the Mexican tableland. They comprise all the species that I have so far been able to recognize from the temperate portions of North America. None of the twenty-seven Mexican species described by $\mathrm{Mr}$. v. d. Wulp are included. They mostly belong to the neotropical fauna. I am under many obligations to Mr. S. H. Scudder for sending me, some years ago, the types of the dipterous parasites mentioned in his Butterflies of the Eastern United States and Canada. It was a study of these, and comparison of them with other types which I then possessed, that enabled me to prepare the following table of Exorista, as well as a similar one of the allied genera Masicera and Thorocera. I have examined all the species mentioned in the table.
Table of Species.

I. Palpi wholly black or dark brownish . . . . 2 Palpi wholly or partly yellow or rufous yellow . . . 5

2. Second abdominal segment with both discal and marginal macrochaetae . . . . 3

Second segment with only marginal macrochaetae

3. Anal segment unusually bristly, rather strongly and.thickly so

hirsuta

Abdomen with only the usual bristles . . nigripalpis

4. Anal segment brassy yellow pollinose . . . futilis

Abdomen shining black and silvery, without brassy pollen on anal segment . . theclarum

5. Second and third segments with both discal and marginil macrochaetae 

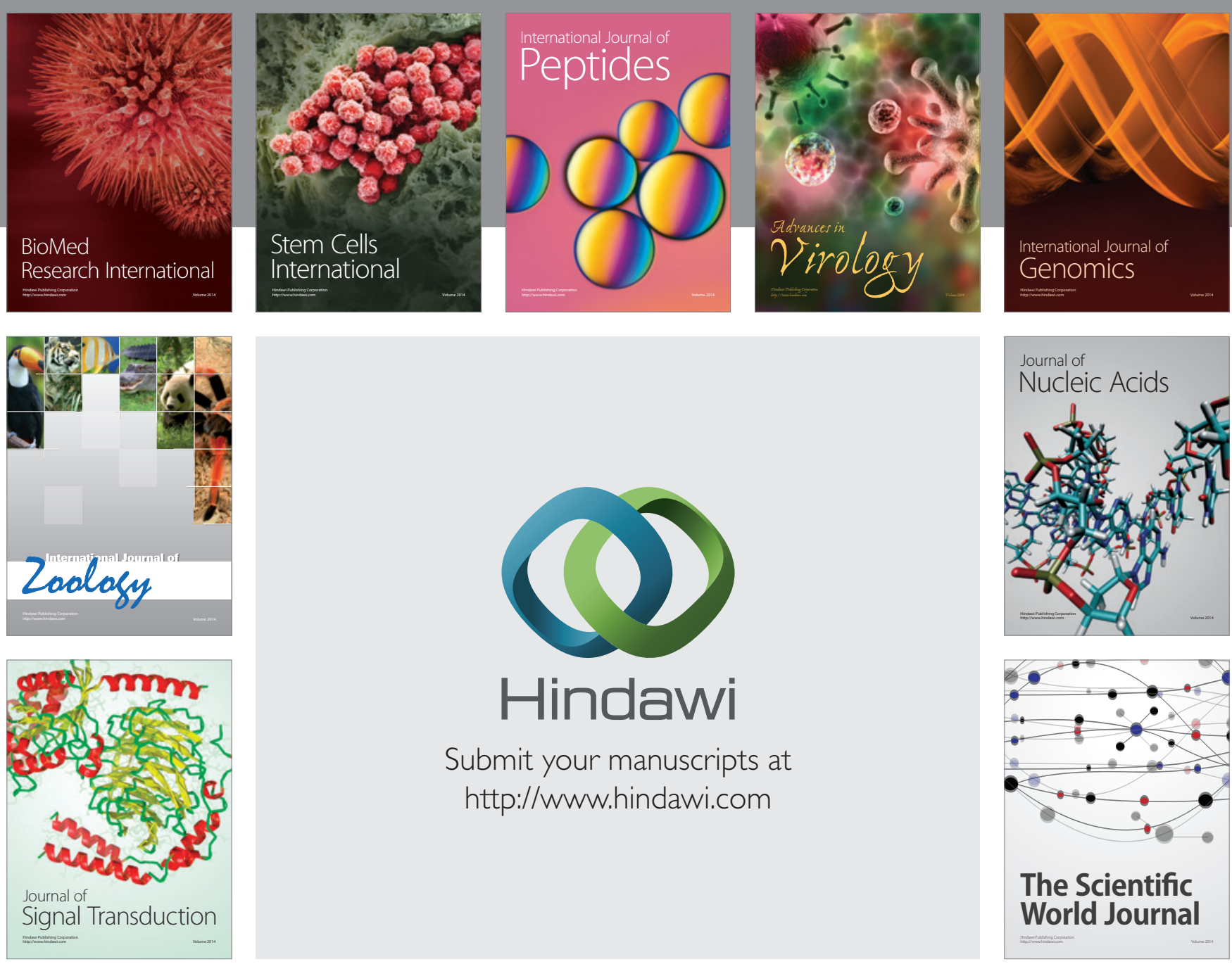

Submit your manuscripts at

http://www.hindawi.com
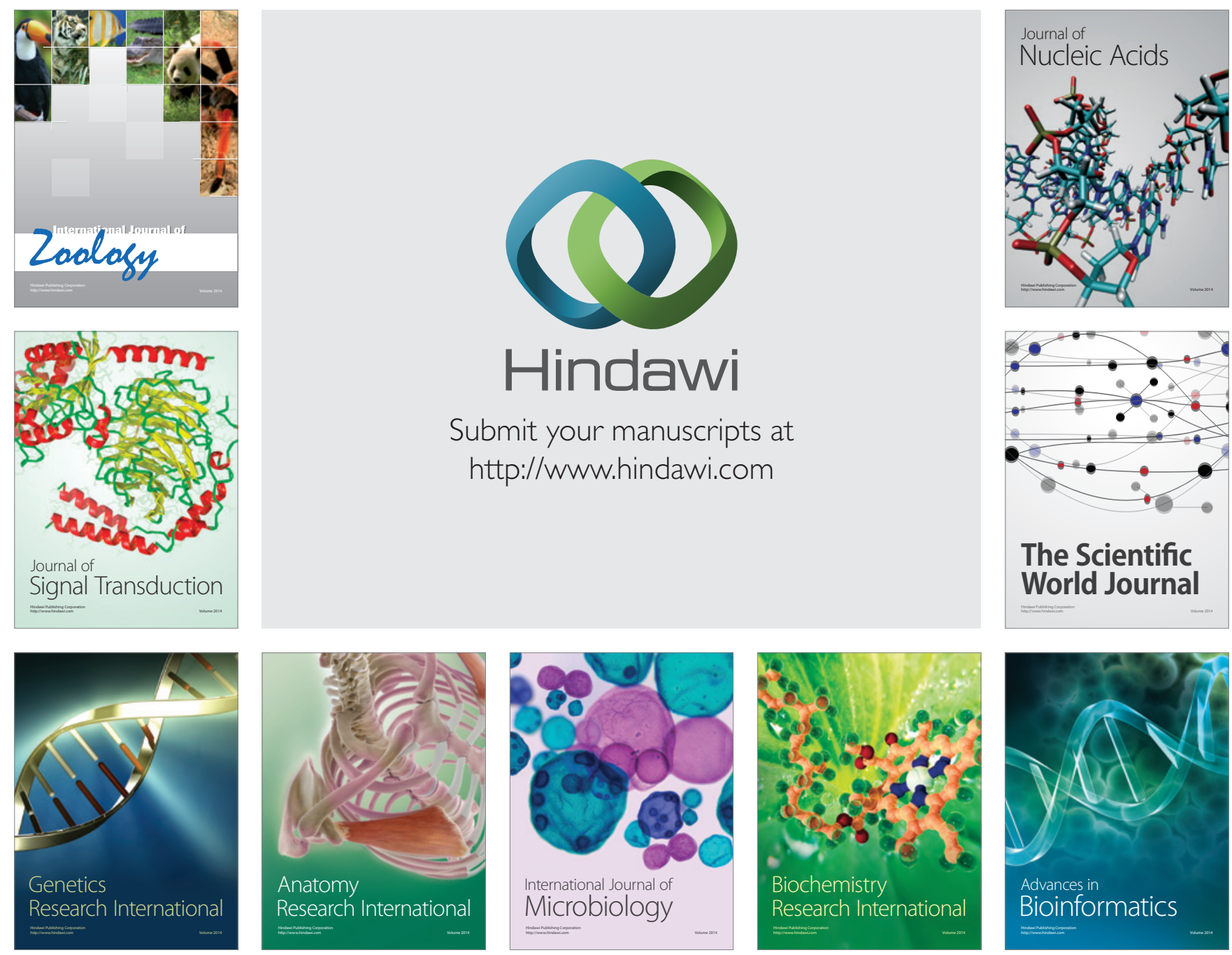

The Scientific World Journal
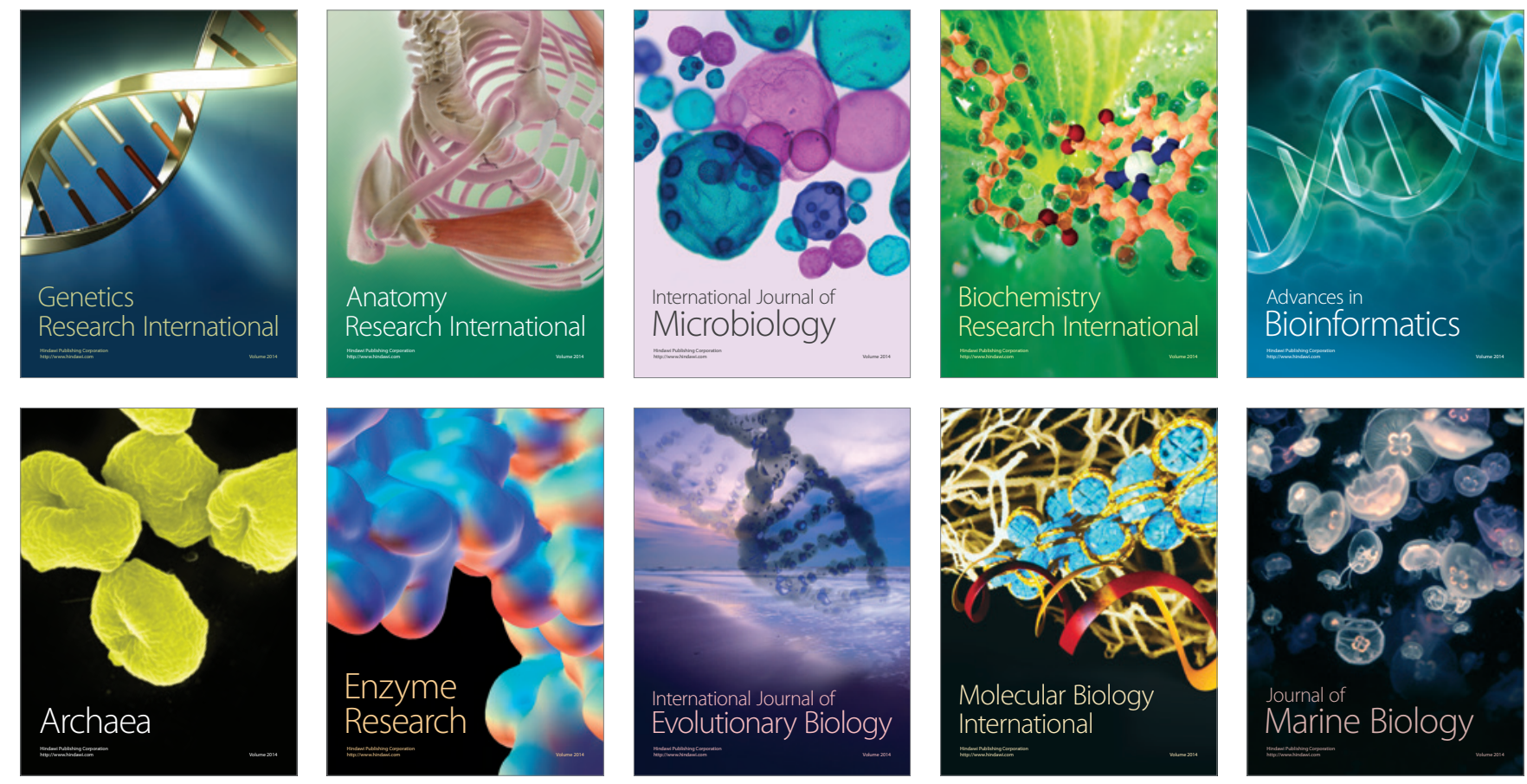